\title{
Size-dependent impacts of the endangered white-clawed crayfish (Austropotamobius pallipes) (Lereboullet) on the littoral community
}

\author{
P.J. Rosewarne ${ }^{(1)}$, R.J.G. Mortimer ${ }^{(2)}$, A.M. Dunn ${ }^{(1), \star}$
}

Received February 27, 2013

Revised April 11, 2013

Accepted April 15, 2013

\section{ABSTRACT}

Key-words: crayfish, mesocosm, ontogenic diet-shift, Austropotamobius pallipes, conservation

The demise of Britain's only native crayfish (Austropotamobius pallipes (Lereboullet)) has prompted conservation-led translocations to safe isolated stillwaters (Ark sites). Many translocations represent introductions rather than re-stocking; hence it is important to ensure that there will not be a detrimental impact on communities already present. Current knowledge is insufficient to predict likely effects, although gut contents analyses suggest that $A$. pallipes is omnivorous and exhibits ontogenic diet shifts. A mesocosm study was conducted with the aim to first, determine community impacts of introducing $A$. pallipes on the benthic invertebrate community, and second investigate if impacts vary with crayfish life-stage. All crayfish life-stages strongly reduced shredder and grazer abundance, particularly thin-shelled Lymnaea snails. The small snail Physa fontinalis was preferentially consumed by juveniles, perhaps reflecting different preyhandling ability. Adults showed greater reliance on terrestrially derived detritus compared to juveniles. There were limited effects on other trophic levels, although by reducing shredders that process basal resources, crayfish impacts may be felt through the community in the long-term.

\section{RÉSUMÉ}

Impacts dépendant de la taille de l'écrevisse à pattes blanches (Austropotamobius pallipes) (Lereboullet) sur la communauté littorale

Mots-clés : écrevisse, mésocosmes, changement ontogénique de régime, Austropotamobius pallipes, conservation
L'effondrement en Grande-Bretagne de la seule espèce indigène d'écrevisse Austropotamobius pallipes (Lereboullet) a incité les transferts à but de conservation dans des milieux aquatiques isolés et sûrs (sites Ark). De nombreuses translocations représentent des introductions plutôt que la reconstitution de stocks, et il est important de s'assurer qu'il n'y aura pas un impact négatif sur les communautés déjà présentes. Les connaissances actuelles sont insuffisantes pour prévoir les effets probables, bien que les analyses des contenus stomacaux suggèrent que $A$. pallipes est omnivore et présente des changements ontogéniques de régime. Une étude en mésocosmes a été menée dans le but d'abord, de déterminer les impacts de l'introduction d'A. pallipes sur la communauté d'invertébrés benthiques, puis d'étudier si les effets varient en fonction du stade de vie des écrevisses. Tous les stades de vie de l'écrevisse ont fortement réduit l'abondance des déchiqueteurs et des brouteurs, en particulier les escargots Lymnaea à coquilles minces. Le petit escargot $P$ hysa fontinalis a été préférentiellement consommé par les jeunes,

(1) School of Biology, Faculty of Biological Sciences, University of Leeds, Leeds LS2 9JT, UK

(2) School of Earth and Environment, University of Leeds, Leeds LS2 9JT, UK

* Corresponding author: a.dunn@leeds.ac.uk 
reflétant peut-être une capacité de capture de proie différente. Les adultes ont montré une plus grande dépendance à l'égard des détritus d'origine terrestre par rapport aux juvéniles. II y avait des effets limités sur les autres niveaux trophiques, mais en réduisant les broyeurs qui consomment des ressources de base, les impacts de l'écrevisse peuvent être ressentis par la communauté dans le long terme.

\section{INTRODUCTION}

Translocation of animals, whether it be movement of imminently threatened populations or reintroduction to restored habitats, is a widely used tool for the conservation of both terrestrial and aquatic species (Seddon et al., 2007; Armstrong and Seddon, 2008). The endangered white-clawed crayfish (Austropotamobius pallipes (Lereboullet)) has declined across its range since the introduction of the invasive signal crayfish (Pacifasticus leniusculus) to Europe in the 1960s (Lewis and Holdich, 2002). Pacifastacus leniusculus outcompetes A. pallipes and is a vector of Aphanomyces astaci, the cause of 'crayfish plague', which is fatal to A. pallipes (Alderman et al., 1990; Peay and Rogers, 1998). In the absence of effective means to control the spread of invasive crayfish or plague, translocation of imminently threatened populations of $A$. pallipes to isolated locations (Ark sites) has become a key part of current conservation strategy for the species (Kozák et al., 2011).

Two of the five most important criteria for the selection of recipient Ark sites are absence of non-native crayfish and low risk of future invasion (Peay, 2009). Isolated waterbodies, such as natural lakes and restored quarries or gravel pits, represent the most biosecure sites available and the majority do not hold existing crayfish populations (Kindemba et al., 2009). Translocations to Ark sites therefore commonly represent introductions, i.e. attempts to establish a species outside its recorded distribution. Recommendations from the International Union for Conservation of Nature (IUCN) state that such introductions are a feasible conservation tool, though assessment of likely impacts on the existing ecosystem is necessary to avoid unforeseen ecological consequences (IUCN, 2012).

Introduced species have potential to impact the existing ecology, for example through predation, habitat modification or release of pathogens (Conant, 1988; Hodder and Bullock, 1997), and the need to exercise caution during translocations is frequently voiced (e.g. Hodder and Bullock, 1997; Carter and Newbery, 2004). Crayfish are opportunistic omnivores, yet selective consumers; hence community impacts are predominantly mediated through dietary choices, causing direct and indirect effects at a range of trophic levels (Nyström et al., 1999; Usio and Townsend, 2002; Dorn and Wojdak, 2004). Presence of crayfish of Astacus sp. has been associated with reduction in submerged macrophytes (Nyström and Strand, 1996; Nyström et al., 1999), reduced biomass of grazers, particularly gastropods, and shifts in community composition towards predatory invertebrates (Nyström et al., 1999). Some crayfish species are also significant bioturbators, modifying sediment transport and increasing turbidity (Harvey et al., 2011; Johnson et al., 2011), with indirect effects on algae and macrophyte cover (Dorn and Wojdak, 2004; Usio et al., 2009). Palatability and preference tests suggest dietary choices of crayfish are dependent on nutritional content (Adams et al., 2005), past experience (Gherardi and Barbaresi, 2007), and ease of capture (Brown, 1998); while field-based foraging patterns reflect a complex balance between food preference and competition (Gherardi et al., 2001). The diet of $A$. pallipes, examined indirectly through gut content analyses of field-caught specimens or through laboratory preference and predation tests, indicates generalist omnivory with a wide range of food types including terrestrially derived detritus, algae, molluscs, isopods, fish and fish eggs, amphipods and insect larvae (Gherardi et al., 2001; Reynolds and O'Keeffe, 2005; Scalici and Gibertini, 2007). Gut analysis also provides evidence of an ontogenic diet shift in A. pallipes, as evidenced for other crayfish species e.g. P. leniusculus (Guan and Wiles, 1998) and Procambarus clarkii (Correia, 2003), with juvenile diet comprising a greater proportion of micro-crustaceans, whereas adults consume more vegetal items 
such as macrophytes, woody fragments and aufwuchs (Reynolds and O'Keeffe, 2005). In view of this, it may be predicted that crayfish impacts on existing communities will vary with population structure. The influence of $A$. pallipes on the littoral community has been previously investigated by Matthews et al. (1993) who found a reduction in Chara, Chironomidae, Gammarus and Hemiptera biomass when $A$. pallipes were reintroduced to enclosures in a mesotrophic marl lake system; though the size range of crayfish studied was not indicated. We used a field-based mesocosm experiment to assess the short-term impacts of $A$. pallipes introduction on the benthic invertebrate community, and to test the hypothesis that impacts differ between juvenile and adult life-stages of crayfish.

\section{MATERIALS AND METHODS}

The experiment was conducted August-September 2010 using outdoor mesocosm pools ( $n=$ 12) to mimic lentic Ark sites. Mesocosms overcome some of the limitations of gut contents analyses such as providing only a snapshot of diet at the moment of capture, and bias due to over representation of less digestible diet items (Correia, 2003). Pools were seeded with identical communities of plants, detritus and invertebrates to reflect flora and fauna which are widespread in the UK. Individuals of $A$. pallipes were introduced to the pools at the start of the experiment within four treatments: juvenile crayfish, adult crayfish, mixed juvenile and adult crayfish, and a no crayfish control, using a randomised-block design with 3 replicates in each. The experiment lasted 5 weeks after which we recovered and counted all the remaining invertebrates in each pool, and weighed the macrophytes and detritus.

\section{$>$ MESOCOSM SETUP}

Plastic pools $\left(0.78 \mathrm{~m}^{2}, 1 \mathrm{~m}\right.$ diameter, $0.65 \mathrm{~m}$ depth) were sunk into a meadow at the University of Leeds Field Research Unit, UK. The rim of each pool was positioned $15 \mathrm{~cm}$ above ground level to prevent accidental drowning by insects and small mammals. Pools were filled to $35 \mathrm{~cm}$ depth with groundwater and seeded with additional lake water $(3 \mathrm{~L})$ to facilitate the development of phytoplankton and zooplankton communities. Lids were placed over the pools, each with a central circular opening ( $50 \%$ area) to enable light penetration yet limit extreme temperature fluctuations. Netting $(20 \mathrm{~mm}$ mesh) was secured over the opening to prevent both crayfish escaping and predation by birds, and to reduce leaf litter inputs.

Macrophytes, Ceratophyllum demersum (65 g wet mass), Elodea nuttallii (65 g) and Potamogeton natans $(25 \mathrm{~g})$ were added to the pools on 5th August. Stems were secured within 12 shallow circular trays (300mm diameter, $40 \mathrm{~mm}$ depth) filled with $60: 40$ mix of pure sand and dried loam soil. These were placed in the centre of each pool and covered with a layer of gravel. A slope of gravel extended approximately $10 \mathrm{~cm}$ beyond the margin of the tray to the floor of the pool, thereby enabling crayfish access to the plants. Allochthonous detritus $(100 \mathrm{~g}$ wet mass), as leaves of beech ( $80 \%)$ and alder ( 20\%) soaked for over 2 months, was also added to each pool.

Pools were left to stabilise for 3 weeks before stocking the invertebrates and crayfish. The following macro-invertebrates were added to each pool: 6 Lymnaea stagnalis $(20-30 \mathrm{~mm}$, total length (TL)), 10 Planorbarius corneus (15-22 mm, TL), 60 Physa fontinalis (6-9 mm, TL), 8 Bithynia tentaculata (9-14 mm, TL); 57 Gammarus pulex (9-16 mm, TL), 52 Asellus aquaticus (10-14 mm, TL) and 80 chironomid larvae. All were collected from still or slow-flowing waters nearby, except the chironomid larvae which were purchased live from a local pet retailer, and densities within the pools approximately reflected those found in the source sites.

Crayfish were collected from the Aire catchment, Yorkshire, held within the laboratory for at least one week under 16:8 light/dark regime at $16{ }^{\circ} \mathrm{C}$ and fed crab pellets (Hinari) ad libitum, before being placed in the pools. All crayfish were numbered on the cephalothorax using non-toxic correction fluid to enable recognition of individuals, then weighed (wet weight) and measured (carapace length, CL). Eight sections of PVC pipe $(2 \times 50 \mathrm{~mm}$ dia meter, $120 \mathrm{~mm}$ length; $6 \times 25 \mathrm{~mm}$ dia meter, $80 \mathrm{~mm}$ length) were also added to serve as refugia, with a view to reducing aggressive interactions and post-moult cannibalism. 


\section{DEXPERIMENTAL DESIGN}

Crayfish were assigned to the three treatments based primarily on mass, with the aim to reduce variation in total mass between treatments. Juvenile treatment comprised 6 juveniles $(2.1-5.5 \mathrm{~g}, 16.1-24.2 \mathrm{~mm} \mathrm{CL})$, adult treatment comprised 2 adults (12-22.7 g, $31.6-38.9 \mathrm{~mm} \mathrm{CL})$, and mixed treatment comprised 1 adult $(12.1-16.1 \mathrm{~g}, 33.2-36.1 \mathrm{~mm} \mathrm{CL})$ and 4 juveniles (1.87-2.78 g, 17.5-20.4 mm CL). Crayfish densities in the pools ranged from 2.56 to 9 individuals $\mathrm{m}^{-2}$. Mean total mass of crayfish did not vary significantly between pools within the same treatment (23.4 $\pm 3.8 \mathrm{~g}$ S.D., $F=2.8, p=0.09$ (juveniles); $33.7 \pm 3.5 \mathrm{~g}$ S.D., $F=0.223, p=0.81$ (adults); $21.8 \pm 1.9 \mathrm{~g}$ S.D., $F=2.24, p=0.98$ (mixed), ANOVA). The limited availability of study animals meant sex ratios could not be fully balanced between treatments. While there is some evidence for sex-dependent feeding patterns for crayfish in the wild (Gherardi et al., 2004), most studies report no dietary differences due to sex (e.g. Renai and Gherardi, 2004; Reynolds and O'Keeffe, 2005; Stenroth et al., 2008).

Pools were checked weekly for crayfish mortalities and evidence of moult. In the event of mortality, crayfish were replaced with equivalent sized individuals. In the event of ecdysis, moults were removed and identification numbers repainted on post-moult individuals once the carapace had hardened. Water temperature and dissolved oxygen were measured in each pool at weekly intervals during mid-afternoon and sub-surface water samples were also collected at the end of the experiment for subsequent laboratory analyses of nitrate, phosphate, ammonium, calcium, potassium, magnesium and sulphate.

Pools were emptied at the end of the experiment. Macrophytes were removed, blotted dry and reweighed, and all water and sediment were passed through a net of mesh $1 \mathrm{~mm}$ to recover remaining invertebrates and detritus. Invertebrates and detrital fragments were separated from the gravel by hand sorting and then identified to species and counted. Detrital fragments exceeding approximately $4 \mathrm{~mm}$ diameter were collected and weighed.

\section{> STATISTICAL ANALYSIS}

We tested for a treatment effect on the overall change in crayfish mass, and for a difference in percentage mass change between juveniles and adults using an independent samples median test. Treatment effects on the remaining biomass of macrophytes and absolute abundances of macro-invertebrate taxa were tested using one way ANOVA with treatment as a factor. All data were tested for normality using Shapiro-Wilk test and were log $10+1$ transformed where necessary. Levene's test was used to determine compliance with the assumption of homogeneity of variance between groups. Tukey's HSD post-hoc test was use to identify differences between groups if there was a significant overall treatment effect. The Shannon diversity $(\mathrm{H})$ and evenness $\left(\mathrm{E}_{\mathrm{H}}\right)$ indices were calculated for the macro-invertebrate communities present in the pools after 5 weeks and compared across treatments using Kruskal-Wallis independent samples test with 0.05 significance level. All analyses were performed using PASW Statistics 18 (IBM).

\section{RESULTS}

\section{> WATER CHEMISTRY}

Water temperature in the pools varied from 14 to $17{ }^{\circ} \mathrm{C}$ over the study period and there was no significant temperature difference between treatments $\left(F_{3,56}=0.48, p=0.70\right)$. Dissolved oxygen saturation ranged from 89 to $116 \%$ at the weekly checks, and did not differ significantly between treatments $\left(F_{3,56}=0.11, p=0.96\right)$. Treatments did not differ for any other water chemistry parameters measured. 


\section{Table I}

One way ANOVA and Tukey's HSD post-hoc test comparing the biomass of macrophytes and abundances of invertebrate taxa remaining in pools after 5 weeks under 3 crayfish treatments (juveniles only $(J)$; Adults only (A); and mix of juveniles and adults $(M)$, and control $(C)$ with no crayfish.

\begin{tabular}{|c|c|c|c|c|c|c|c|c|}
\hline & \multicolumn{2}{|c|}{ Treatment } & \multirow{2}{*}{\begin{tabular}{|c|} 
J vs. A \\
$p$
\end{tabular}} & \multirow{2}{*}{\begin{tabular}{|c|} 
J vs. M \\
$p$
\end{tabular}} & \multirow{2}{*}{$\frac{A \text { vs. M }}{p}$} & \multirow{2}{*}{$\frac{\mathrm{J} \text { vs. C }}{p}$} & \multirow{2}{*}{\begin{tabular}{|c|} 
M vs. C \\
$p$
\end{tabular}} & \multirow{2}{*}{$\frac{A \text { vs. C }}{p}$} \\
\hline & $F_{3,8}$ & $p$ & & & & & & \\
\hline \multicolumn{9}{|l|}{ Macrophyte biomass } \\
\hline Potamogeton natans & 2.23 & 0.16 & - & - & - & - & - & - \\
\hline Ceratophyllum demersum & 1.52 & 0.28 & - & - & - & - & - & - \\
\hline Elodea nutallii & 3.87 & 0.06 & - & - & - & - & - & - \\
\hline Detrital leaves & 10.78 & $<0.01$ & 0.30 & 0.09 & 0.80 & 0.14 & $<0.01$ & $<0.01$ \\
\hline \multicolumn{9}{|l|}{ Grazers } \\
\hline Bithynia tentaculata & 2.149 & 0.17 & - & - & - & - & - & - \\
\hline Physa fontinalis & 20.03 & $<0.01$ & $<0.05$ & 0.74 & $<0.01$ & $<0.01$ & $<0.01$ & 0.50 \\
\hline Planorbarius corneus & 17.37 & $<0.01$ & 0.11 & 0.59 & 0.58 & $<0.05$ & $<0.01$ & $<0.01$ \\
\hline Lymnaea sp. & 11.62 & $<0.01$ & 0.78 & 0.89 & 0.40 & $<0.01$ & $<0.05$ & $<0.01$ \\
\hline \multicolumn{9}{|l|}{ Shredders } \\
\hline Gammarus pulex & 4.22 & $<0.05$ & 0.97 & 0.79 & 0.95 & 0.16 & $<0.05$ & 0.09 \\
\hline Asellus aquaticus & 32.24 & $<0.01$ & 0.96 & 0.98 & 0.99 & $<0.01$ & $<0.01$ & $<0.01$ \\
\hline \multicolumn{9}{|l|}{ Filterers/collectors } \\
\hline Chironomid larvae & 10.18 & $<0.01$ & 0.99 & 0.72 & 0.55 & $<0.05$ & $<0.01$ & $<\mathbf{0 . 0 5}$ \\
\hline
\end{tabular}

\section{$>$ CRAYFISH}

Two juvenile crayfish were found dead on day 28 of the experiment, both in small treatment pools, and one was partially consumed. Both were removed and replaced with crayfish of similar mass. Four individuals, all juveniles, successfully moulted during the 35 day study period. Change in total crayfish biomass was highly variable between pools within the same treatment. Mean total mass increase per pool was $5.51 \pm 7.8 \mathrm{~g}(20.4 \%), 1.21 \pm 1.3 \mathrm{~g}(5.8 \%)$ and $2.34 \pm 1.5 \mathrm{~g}(7.3 \%)$ for the juvenile, mixed and adult treatments respectively, with no treatment effect $\left(T_{2}=4.56, p=0.10\right.$, Independent samples median test); however juvenile crayfish experienced a significantly higher percentage change in mass compared to adults, irrespective of treatment $\left(T_{1}=7.26, p<0.05\right.$, Independent samples median test).

\section{>MACROPHYTES AND MACRO-INVERTEBRATES}

There was no treatment effect on the biomass of the 3 macrophyte species, however the mass of detrital leaves was significantly reduced relative to control in both treatments where adults were present (mean overall reduction of 70 and $74 \%$ in adult and mixed treatments, respectively), though not when only juveniles were present (mean $63 \%$ reduction) $\left(F_{3,8}=\right.$ $10.78, p<0.01$ ) (Table I). Detrital leaves in the control treatment were reduced on average by $53 \%$ (Figure 1).

With the exception of the gastropod $B$. tentaculata, there was a treatment effect on the abundances of all benthic invertebrates at the end of the 35 day period (Table I). Of the grazers, abundance of the small gastropod $P$. fontinalis was significantly lower in the juvenile and mixed treatments, relative to the adult treatment ( $p<0.05$ and $p<0.01$, respectively), but there was no difference in abundance between adult treatment and control $(p=0.50)$ (Table I) (Figure 2). Mean abundance of $B$. tentaculata increased in all treatments by an average of $40 \%$; these were all comprised of juveniles. For the other gastropod species ( $P$. corneus and Lymnaea sp.) there was no difference in remaining abundances between the different crayfish treatments (Table I).

The shredder Asellus aquaticus was significantly reduced in all treatments relative to control $\left(F_{3,8}=32.24, p<0.01\right)$, whereas Gammarus pulex was only reduced in the mixed treatment relative to control $\left(F_{3,8}=4.2, p<0.05\right)$ (Figure 2). There was no difference in shredder abundances between crayfish treatments (Table I). The abundance of Chironomid larvae was 


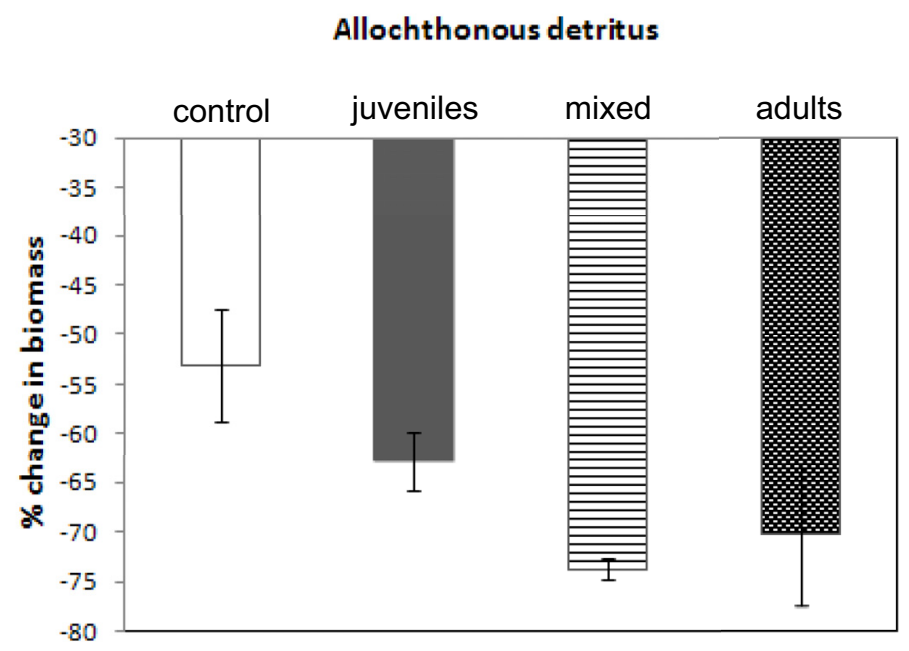

Figure 1

Percentage change $( \pm$ S.D.) in biomass of allochthonous detritus over 5 weeks in mesocosms under 3 crayfish treatments: juveniles; mixed (juveniles and adults), and adults only, and with no crayfish (control).

significantly reduced in all crayfish treatments relative to the control $\left(F_{3,8}=10.18, p<0.01\right)$, with no differences between crayfish treatments (Table I, Figure 2).

Several other species colonised the pools during the experiment including Callicorixa praeusta and damselfly larvae (Coenagrion sp.); however they occurred only at low abundances with generally less than 4 individuals per pool.

The Shannon diversity index in each pool ranged from 0.87 to 1.44 , and did not vary between treatments $\left(H_{3,12}=7.78, p=0.05\right)$. Shannon evenness ranged from 0.24 to 0.49 , and again did not vary between treatments $\left(H_{3,12}=6.08, p=0.11\right)$.

\section{DISCUSSION}

Presence of the crayfish $A$. pallipes had a strong influence on the abundances of benthic invertebrates and on the biomass of detritus in the littoral community over the short-term. However, their presence did not have an influence on the macrophytes. Ontogenic differences were apparent in a species shift among grazers.

The 3 macrophyte species present within the pools did not appear to be important food items for either adults or juveniles of $A$. pallipes, although terrestrially derived detritus was reduced in the presence of adult crayfish. Both G. pulex and $A$. aquaticus function as shredders processing these basal resources within freshwater systems; $A$. aquaticus was significantly reduced in all crayfish treatments, and G. pulex in the mixed treatment, which infers that reduction in detrital leaves was predominantly due to direct consumption from crayfish. Previous results of gut content analysis similarly infer greater consumption of detritus among adults (Reynolds and O'Keeffe, 2005) which may be explained by lower energy demands for growth within the adult life-stage compared to juveniles (Whitledge and Rabeni, 1997); indeed, our juvenile crayfish showed a three fold higher increase in mass than adults during the experiment. However, adults have been shown to adopt a more protein rich diet comprising a greater proportion of macroinvertebrates during times of high energy demand (e.g. breeding) (Stenroth et al., 2008).

In a study of $P$. leniusculus, Nyström et al. (1996) concluded that the activity level of a prey type is the most important determinant on their consumption by crayfish, with a shift towards a community dominated by sediment dwelling taxa in the presence of crayfish. In accord with this, $A$. aquaticus was more reduced than $G$. pulex in all treatments, which likely reflects the ease of capturing this slow moving isopod (Nyström et al., 1996); and also, since there 

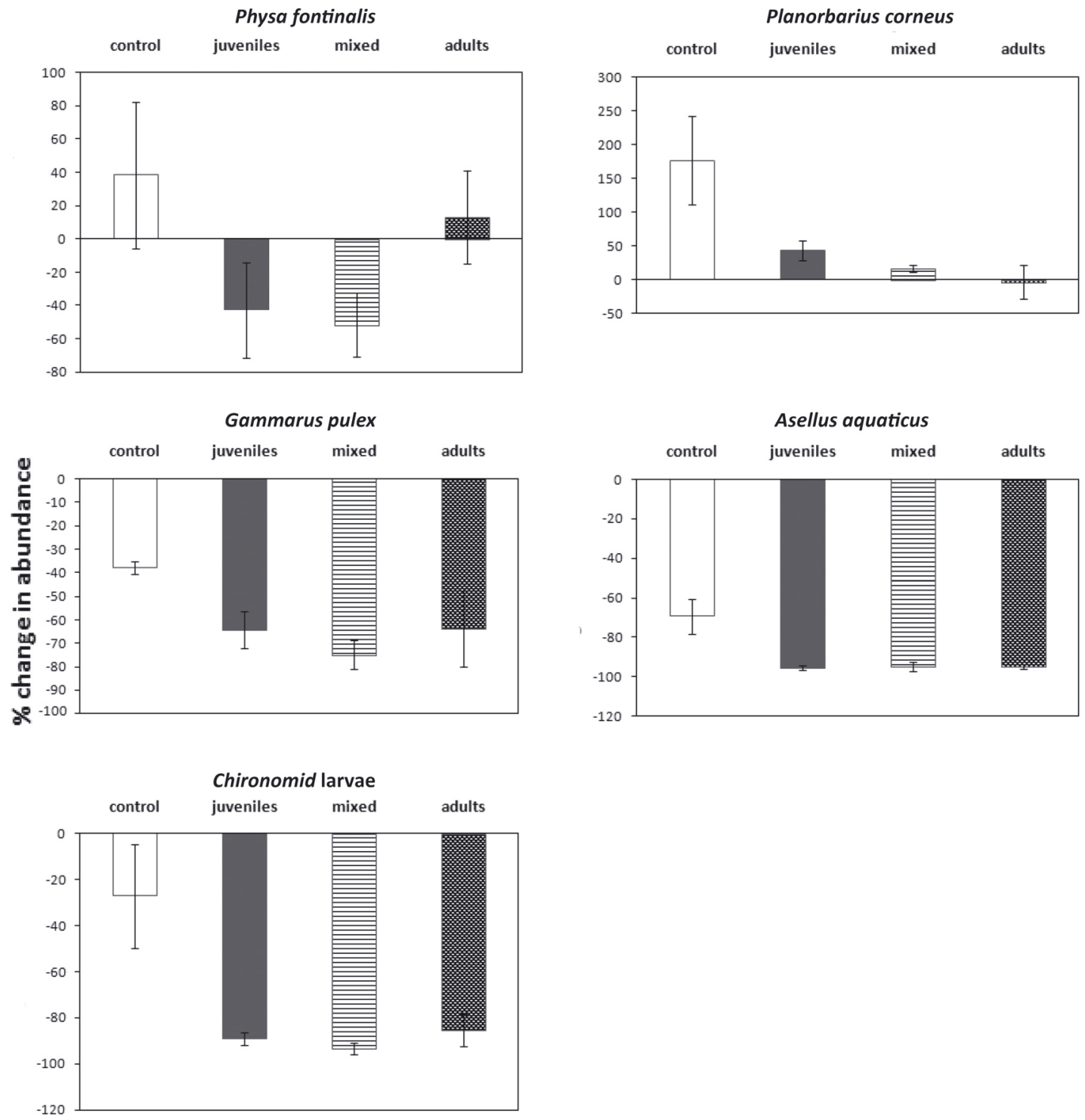

Figure 2

Percentage change ( \pm S.D.) in abundance of grazers (gastropods Physa fontinalis and Planorbarius corneus), shredders (Asellus aquaticus and Gammarus pulex) and filterers (Chironomid larvae) over 5 weeks in mesocosms under 3 crayfish treatments: juveniles; mixed (juveniles and adults), and adults only, and with no crayfish (control).

was a decrease in the controls, perhaps predation by other invertebrates such as G. pulex (Macneil et al., 1997). The reduction of G. pulex in the control pools, though to a lesser degree than $A$. aquaticus, may reflect post-moult cannibalism (Dick, 1995), or reduced survival due to unfavourable conditions (e.g. food or shelter). The high predation level of sediment-dwelling Chironomid larvae in the crayfish treatments ( 81 to $87 \%$ ) is likely to be higher than in natural environments due to the relatively shallow depth of sediment in the pools, and therefore less opportunity to escape predation.

As slow moving species, snails are highly vulnerable to crayfish predation (Lodge et al., 1994; Nyström et al., 1996). This was apparent in the current study, with the exception of $B$. tentaculata which increased in abundance, presumably as a consequence of reproduction by adults, or perhaps hatching of eggs present on plants at the start of the experiment. It is suggested that the presence of the operculum and thicker shell of this species makes it less 
preferable to crayfish compared to the thinner-shelled species such as Lymnaea spp. (Brown, 1998; Nyström et al., 1999). Predation upon P. fontinalis was dependent upon crayfish size, with greater consumption among juveniles. One possible explanation for this may be the differential ability of adults and juveniles to handle these small snails. Reynolds and O' Keeffe (2005) supposed that the size of $A$. pallipes is inversely related to motility of its prey, yet the current study suggests that physical size of the prey is also important. This finding highlights that once crayfish are introduced to an Ark site, the influence on specific species such as the shift towards predation resistant gastropods, is likely to change as the crayfish population structure changes from that dominated by the adult donor stock (Souty-Grosset and Reynolds, 2009), to greater representation by the smallest size classes.

Over the 5 week period of study, we observed a large reduction in the abundance of shredders. Although it is acknowledged that the use of mesocosms may lead to overestimation of predation rates due to more homogenous habitat than in the wild (Nilsson et al., 2008), the changes observed, even if at lower magnitude, are likely to have longer term cascading effects on the community. The predatory impact on shredders may lead to a change in the processing of basal resources, with implications for nutrient cycling and therefore availability to primary producers (Vanni, 2002). However, the current study also highlighted the role of crayfish, particularly adults, in processing basal resources, which may compensate for the loss of shredders in this regard; although a reduction in smaller shredders will likely have knock on effects on other higher order predators that compete with crayfish, for example, fish.

\section{ACKNOWLEDGEMENTS}

This work was funded by NERC case-studentship to PJR and carried out under license from Natural England (20103521). The authors would like to thank project partners Lafarge Tarmac for funding and assistance; Emma Pickering for field assistance, and two anonymous reviewers who contributed valuable suggestions for improving the original manuscript.

\section{REFERENCES}

Adams J.A., Tuchman N.C. and Moore P.A., 2005. Effects of CO2-altered detritus on growth and chemically mediated decisions in crayfish (Procambarus clarkii). J. North Am. Benthol. Soc., 24, 330-345

Alderman D.J., Holdich D. and Reeve I., 1990. Signal crayfish as vectors in crayfish plague in Britain. Aquaculture, 86, 3-6.

Armstrong D.P. and Seddon P.J., 2008. Directions in reintroduction biology. Trends Ecol. Evol., 23, $20-25$

Brown K.M., 1998. The role of shell strength in selective foraging by crayfish for gastropod prey. Freshw. Biol., 40, 255-260.

Carter I. and Newbery, P., 2004. Reintroduction as a tool for population recovery of farmland birds. Ibis, 146, 221-229.

Conant S., 1988. Saving endangered species by translocation: are we tinkering with evolution? Bioscience, 254-257.

Correia A.M., 2003. Food choice by the introduced crayfish Procambarus clarkii. Ann. Zool. Fenn., 40, 517-528.

Dick J.T.A., 1995. The cannibalistic behaviour of two Gammarus species (Crustacea: Amphipoda). J. Zool. 236, 697-706.

Dorn N.J. and Wojdak J.M., 2004. The role of omnivorous crayfish in littoral communities. Oecologia, 140, 150-159.

Gherardi F. and Barbaresi S., 2007. Feeding preferences of the invasive crayfish, Procambarus clarkii. BFPP-Connaissance Et Gestion Du Patrimoine Aquatique, 7-20. 
Gherardi F., Acquistapace P. and Santini G., 2001. Foraging by a threatened species - the white-clawed crayfish, Austropotamobius pallipes. Archiv. Fur. Hydrobiologie, 152, 339-351.

Gherardi F., Acquistapace P. and Santini G., 2004. Food selection in freshwater omnivores: a case study of crayfish Austropotamobius pallipes. Archiv. Fur. Hydrobiologie, 159, 357-376.

Guan R.Z. and Wiles P.R., 1998. Feeding ecology of the signal crayfish Pacifastacus leniusculus in a British lowland river. Aquaculture, 169, 177-193.

Harvey G.L., Moorhouse, T.P., Clifford, N.J., Henshaw, A.J., Johnson, M.F., Macdonald, D.W., Reid, I. and Rice, S.P., 2011. Evaluating the role of invasive aquatic species as drivers of fine sedimentrelated river management problems: The case of the signal crayfish (Pacifastacus leniusculus). Prog. Phys. Geog., 35, 517-533.

Hodder, K.H. and Bullock J.M., 1997. Translocations of native species in the UK: implications for biodiversity. J. Appl. Ecol., 547-565.

IUCN 2012. IUCN Guidelines for Reintroductions and Other Conservation Translocations.

Johnson M.F., Rice S.P. and Reid I., 2011. Increase in coarse sediment transport associated with disturbance of gravel river beds by signal crayfish (Pacifastacus leniusculus). Earth Surf. Process. Landf., 36, 1680-1692.

Kindemba V., Whitehouse A. and Peay S., 2009. Using GIS to prioritise and identify regional Ark sites for whiteclawed crayfish: South west aggregate and mineral extraction sites. Buglifethe Invertebrate Conservation Trust, Peterborough, $19 \mathrm{p}$.

Kozák P., Füreder L., Kouba A., Reynolds J. and Souty-Grosset C., 2011. Current conservation strategies for European crayfish. Knowl. Managt. Aquatic Ecosyst., 401, 1-8.

Lewis S. and Holdich D., 2002. Pacifastacus. Biology Freshwater Crayfish, 511-540.

Lodge D.M., Kershner M.W., Aloi J.E. and Covich A.P., 1994. Effects of an omnivorous crayfish (Orconectes rusticus) on a freshwater littoral food-web. Ecology, 75, 1265-1281.

Macneil C., Dick J.T.A. and Elwood R.W., 1997. The trophic ecology of freshwater Gammarus spp. (Crustacea:amphipoda): problems and perspectives concerning the functional feeding group concept. Biol. Rev., 72, 349-364.

Matthews M., Reynolds J. and Keatinge M., 1993. Macrophyte reduction and benthic community alteration by the crayfish Austropotamobius pallipes (Lereboullet). Freshw. Crayfish 9, 289-299.

Nilsson E., Olsson K., Persson A., Nyström P., Svensson G. and Nilsson U., 2008. Effects of stream predator richness on the prey community and ecosystem attributes. Oecologia, 157, 641-651.

Nyström P. and Strand J.A., 1996. Grazing by a native and an exotic crayfish on aquatic macrophytes. Freshw. Biol., 36, 673-682.

Nyström P., Bronmark C. and Graneli W., 1996. Patterns in benthic food webs: A role for omnivorous crayfish? Freshw. Biol., 36, 631-646.

Nyström P., Bronmak C. and Graneli W., 1999. Influence of an exotic and a native crayfish species on a littoral benthic community. Oikos, 85, 545-553.

Peay S., 2009. Selection criteria for "ark sites" for white-clawed crayfish. Crayfish Conservation in the British Isles, 63.

Peay S. and Rogers D., 1998. The peristaltic spread of signal crayfish (Pacifastacus leniusculus) in the River Wharfe, Yorkshire, England. Freshw. Crayfish, 12, 665-676.

Renai B. and Gherardi F., 2004. Predatory efficiency of crayfish: comparison between indigenous and non-indigenous species. Biol. Invasions, 6, 89-99.

Reynolds J.D. and O'Keeffe C., 2005. Dietary patterns in stream- and lake-dwelling populations of Austropotamobius pallipes. Bull. Fr. Pêche Piscic., 715-730.

Scalici M. and Gibertini G., 2007. Feeding habits of the crayfish Austropotamobius pallipes (Decapoda, Astacidae) in a brook in Latium (central Italy). Ital. J. Zool., 74, 157-168.

Seddon P.J., Armstrong D.P. and Maloney R.F., 2007. Developing the Science of Reintroduction Biology, Conserv. Biol., 21, 303-312.

Souty-Grosset C. and Reynolds J., 2009. Current ideas on methodological approaches in European crayfish conservation and restocking procedures. Knowl. Managt. Aquatic Ecosyst., 394-395, $1-11$.

Stenroth P., Holmqvist N., Nyström P., Berglund O., Larsson P. and Graneli W., 2008. The influence of productivity and width of littoral zone on the trophic position of a large-bodied omnivore. Oecologia, 156, 681-690. 
Usio N. and Townsend C.R., 2002. Functional significance of crayfish in stream food webs: roles of omnivory, substrate heterogeneity and sex. Oikos, 98, 512-522.

Usio N., Kamiyama R., Saji A. and Takamura N., 2009. Size-dependent impacts of invasive alien crayfish on a littoral marsh community. Biol. Conserv., 142, 1480-1490.

Vanni M.J., 2002. Nutrient cycling by animals in freshwater ecosystems. Annu. Rev. Ecol. Syst., 341-370.

Whitledge G.W. and Rabeni C.F., 1997. Energy sources and ecological role of crayfishes in an Ozark stream: insights from stable isotopes and gut analysis. Can. J. Fish. Aquat. Sci., 54, 2555-2563. 